\title{
The Analysis of Temps Verbaux (Verb Tenses) in French and Its Indonesian Equivalent
}

\author{
$1^{\text {st }}$ Balduin Pakpahan ${ }^{1}, 2^{\text {nd }}$ Zulherman $^{2}, 3^{\text {rd }}$ Lellyta Tri Pawani ${ }^{3}, 4^{\text {th }}$ Bobi Mulyadi Hasibuan ${ }^{4}$ \\ \{balduinpakpahan113@gmail.com ${ }^{1}$, zulhermanghani@yahoo.com ${ }^{2}$, lellytatripawani@gmail.com ${ }^{3}$ \} \\ Universitas Negeri Medan, Indonesia ${ }^{1,2,3,4}$
}

\begin{abstract}
Tenses, aspect, and mode are associated with verbs in all languages. French has those three elements that even frequently overlapped while Indonesian does not have those elements. Verb mastery with the scope of tenses, aspect, and mode is very crucial in mastering four French language skills. This pragmatic research was conducted to analyze the switching of contextual meanings that have temps verbaux with pragmatic conjunctions, personal pronouns, ad ellipsis on the speech acts of French as the original language to Indonesian as the target language and vice versa. The sources used in this study are L'Etranger by Albert Camus translated to Orang Asing by Apsanti Djokosujatno and Keberangkatan by Nh. Dini translated to Le Départ by Lauren Metzger. Observing and note taking are used as the research method followed by Pilah Unsur Penentu Technique (PUP) (basic technique) and Hubung Banding Menyamakan Technique (advanced technique).
\end{abstract}

Keywords: Equivalent Words, Meanings, Verb Tenses.

\section{Introduction}

In the era of global growth where borders of the state as if no longer exist, the mastery of foreign language has become one of the most important values especially in trade documentation, international affairs, and also bilingual and multilingual communication. French is one of the most spoken languages. Besides, according to UNESCO, approximately $71 \%$ of scientific literature has been written in French, German, and English [1]. This makes the mastery of French an added value for an individual. The mastery of foreign language is not only enough to master language components such as grammar, phonology, and vocabulary but must be in a broader context that is the ability to translate comprehensively [2].

French has three elements called tense, aspect, and mode. These elements are contained in the verb. Verbs are conjugated words and their forms will change to synchronize with modes, tenses, voices, people, and numbers [3]. Therefore, mastery of verbs with the scope of tense, aspect, and mode is needed to master the four French language skills. In contrast to French, Indonesian is a language that does not have an element called tense. Aspects in Indonesian are expressed with the particles sudah/telah (was), sedang (is), and akan (will) [4]. The particles do not always appear in a sentence. Sentences that do not contain a context or do not contain any of the particles can be considered to have them. This is what raises doubts. The last element is mode. Regarding mode, what is called mode in Indonesian is limited to speech acts that express orders [5]. 
This research was conducted with a focus on observing temps verbaux or verb tenses. Verb tenses or temps verbaux are useful for describing facts or actions shown by verbs in the past, present, and future [6]. This study was conducted to analyse the transition of contextual meaning experienced by temps verbaux in French speech acts as the source language to Indonesian as the target language and vice versa from Indonesian as the source language to French as the target language. Therefore, this research is expected to help Indonesian students to understand the concept of tense, aspect, and mode especially temps verbaux in French.

\section{Method}

This research is pragmatic research that used translated text and source language text as research objects. The source data used in this research is French novel, L'Étranger by Albert Camus (1942) translated into Orang Asing by Apsanti Djokosuyatno (2013) and Indonesian novel, Keberangkatan by Nh. Dini (1977) translated into Le Départ by Lauren Metzger (2013). This research was conducted using the equivalent method (the method of padan) followed by basic and advanced techniques. The basic technique used is the Pilah Unsur Penentu Technique (PUP) and the advanced technique used is Hubung Banding Menyamakan Technique. Pilah Unsur Penentu Technique is used to classify the grammatical meanings of verb conjugation through tense, aspect, and mode that affect the lexical meanings in French and Indonesian. Hubung Banding Menyamakan Technique is connect-compare technique of determining element that is relevant with decided data [7]. The procedure for providing data in this study was carried out through the observation method with an advanced technique namely note-taking technique.

\section{Results and Discussion}

The research has been limited to study one of temps verbaux in French namely the tense in indicative mode (les temps de l'indicatif) which consists of 2 types namely le temps simple and le temps composé. This research was conducted to observe the occurrence of utterances containing verb tenses or temps verbaux dan their equivalent words. The number of utterances that were used as data samples in this study were 10 utterances in each novel.

\subsection{The Occurrence of Temps Verbaux (Verb Tenses) in the French Novel L'Étranger andTheir Equivalents in Indonesian Novel Orang Asing}

The first observation was made on the verb tenses or temps verbaux that appear in the French novel $L$ 'Étranger and the equivalent forms in Indonesian. Observations were made on verbs containing temps verbaux which are identified through the form of the verbs. The verbs containing verb tenses or temps verbaux will be classified based on the type of temps verbaux and observed for the similar context of tense or temps with the Indonesian equivalents. The occurrence of utterances containing verb tenses or temps verbaux in L'Étranger and their equivalents in Indonesian can be seen in Table 1. 
Table 1. The Occurrence of Temps Verbaux (Verb Tenses) in French Novel L'Étranger and Their Translation in Indonesian Novel Orang Asing.

\begin{tabular}{|c|c|c|}
\hline \multirow{2}{*}{ No. } & \multicolumn{2}{|c|}{ TEMPS VERBAUX } \\
\hline & L'Étranger (French) [8] & Orang Asing (Indonesian) [9] \\
\hline 1. & $\begin{array}{l}\text { Aujourd'hui, maman est morte } \\
\text { (page 7) }\end{array}$ & Hari ini ibu meninggal (page 3) \\
\hline 2. & $\begin{array}{l}\text { Pour le moment, c'est un peu } \\
\text { comme si maman n'était pas morte } \\
\text { (page 8) }\end{array}$ & $\begin{array}{l}\text { Saat ini rasanya hampir seperti ibu } \\
\text { belum meninggal (page } 3 \text { ) }\end{array}$ \\
\hline 3. & Il faisait très chaud (page 8) & Harinya sangat panas (page 4) \\
\hline 4. & $\begin{array}{l}\text { J'ai mangé au restaurant, chez } \\
\text { Céleste, comme d'habitude (page } 8 \text { ) }\end{array}$ & $\begin{array}{l}\text { Aku makan di restoran milik Celeste, } \\
\text { seperti biasa (page 4) }\end{array}$ \\
\hline 5. & $\begin{array}{l}\text { Il a perdu son oncle, il y a quelques } \\
\text { mois (page } 8 \text { ) }\end{array}$ & $\begin{array}{l}\text { Ia kehilangan pamannya beberapa } \\
\text { bulan lalu (page } 4 \text { ) }\end{array}$ \\
\hline 6. & J'ai fait le chemin à pied (page 9) & $\begin{array}{l}\text { Aku pergi kesitu berjalan kaki (page } \\
\text { 4) }\end{array}$ \\
\hline 7. & $\begin{array}{l}\text { J'ai lu le dossier de votre mère. } \\
\text { (page 9) }\end{array}$ & $\begin{array}{l}\text { Saya telah membaca berkas tentang } \\
\text { ibu anda (page } 4 \text { ) }\end{array}$ \\
\hline 8. & $\begin{array}{l}\text { Quand elle était à la maison, } \\
\text { maman passait son temps à me } \\
\text { suivre des yeux en silence (page 10) }\end{array}$ & $\begin{array}{l}\text { Ketika masih di rumah, ibu } \\
\text { menghabiskan waktu memandangi } \\
\text { aku ke mana-mana sambil membisu } \\
\text { (page 5) }\end{array}$ \\
\hline 9. & $\begin{array}{l}\text { A ce moment, le concierge est } \\
\text { entré derrière mon dos (page 12) }\end{array}$ & $\begin{array}{l}\text { Pada saat itu penjaga pintu masuk ke } \\
\text { belakang punggungku (page } 6 \text { ) }\end{array}$ \\
\hline 10. & $\begin{array}{l}\text { La garde est entrée à ce moment } \\
\text { (page 15) }\end{array}$ & $\begin{array}{l}\text { Pada waktu itu perawat masuk (page } \\
\text { 8) }\end{array}$ \\
\hline
\end{tabular}

Table 1 presents the utterances containing verb tenses or temps verbaux and their equivalents in Indonesian. Each of these verbs can be seen in bold words. The first utterance contains temps composé in the form of passé composé on the verb est morte. Temps composé can be identified by the presence of an auxiliary verb être while the form of passé composé is identified by a verb form of participe passé. Auxiliary verbs and verbs in temps composé are unified. The basic form of être plus participe passé (verb form in French) is a formula for the moving verbs in French. Mourir (the base form of morte) or its Indonesian equivalent word of meninggal is a verb that moves in French vocabulary. Therefore, the verb est morte can be divided into est as an auxiliary verb and morte as participe passé. Temps composé expresses the finished action. The equivalent words found in Indonesian show a similar context of the tense or temps with the French utterance because the word meninggal is a word with an action that isdirectly completed or finished.

The second utterance also shows the presence of temps composé but in the form of plusque-parfait. The verb that contains temps verbaux is était morte. The verb also has the equivalent word of meninggal in Indonesian. Compared to the previous form of temps composé, there is a quite striking difference which is the form of auxiliary verb était. These two auxiliary verbs come from the same word which is être. Auxiliary verb of était combined with participe passé (verb form in French) becomes the basic formulation in identifying temps composé with the form of plus-que-parfait.

Unlike the two previous utterances, the third utterance contains temps simple in the form of imparfait. Temps simple is identified by the absence of auxiliary verb while the form of 
imparfait are identified by a distinctive verb form. Thus, it is important for French learners to know the alteration of verb form that occurs in each verb tense or temps verbaux. Temps verbaux found in the verb faisait which has the equivalent of harinya in Indonesian. Temps simple show actions that are still ongoing or whose duration is still happening. There is a similar context in these two words, which means that the word harinya is still ongoing.

The fourth utterance contains temps composé in the form of passé composé. Temps verbaux or verb tense is found in $j$ 'ai mange which is equivalent to the word makan in Indonesian. The verb shows a different form with temps passé composé in the first utterance. Auxiliary verb ai comes from the word avoir. Auxiliary verb avoir combined with participe passé (verb form in French) is used to build unmoving verb in French. Makan is considered as one of unmoving verb. Temps composé on j'ai mange indicates an activity that is directly completed or finished. This shows a similar context of tense or temps with its Indonesian equivalent that the word makan is an activity that is directly finished.

The fifth utterance also shows the presence of temps composé in the form of passé composé in verb a perdu. Verb a perdu has equivalent to the word kehilangan in Indonesian which shows an activity that is directly finished. Similar to the verb in the fourth utterance, the verb in the fifth utterance also used the formulation of an auxiliary verb avoir combine with participe passé that means the word kehilangan is considered as an unmoving verb. The same temps verbaux has also shown in the sixth and seventh utterances which contain temps composé in the form of passé composé with unmoving verbs. The sixth utterance has temps verbaux which is in verb $j$ 'ai fait and has the equivalent word of pergi in Indonesian. The two words show a similar context of tense or temps that is a directly finished activity. The seventh utterance contains temps verbaux in verb $j$ 'ai $l u$ with the equivalent word of telah membaca in Indonesian. The equivalent word in this utterance contains the aspect of 'telah' (has) which makes the presence of tense or temps in the French utterance is clear. Both words indicate a finished activity or the noncontinuous duration of activity.

The eighth utterance contains temps simple in the form of imparfait in its two verbs. The first verb is était which is equivalent to the word di in Indonesian. The second verb is passait which is equivalent to the word menghabiskan in Indonesian. These two equivalent words show unfinished activities or continuous duration of activities. In contrast to the eighth utterance, the ninth utterance contains temps composé in the form of passé composé. Temps verbaux is found in verb est entré which is equivalent to the word masuk. The equivalent word indicates an activity or action that has been finished. The same temps verbaux or verb tense appears in the tenth utterance with the same form and meaning of the verb. Temps verbaux is found in verb est entrée which is the equivalent of the word masuk in Indonesian.

Observations that have been made on the data samples show that there are similarities in the choice of context in the Indonesian translation of French utterances in L'Étranger. However, this only happens in the context of time or called temps in French. The equivalent words in each of the verbs do not indicate the existence of tense in Indonesian. This proves a statement said that Indonesian does not have tense [10].

Observations on the ten utterances show that temps verbaux contain in the utterances describe activities that took place in the past. This may be due to the depiction of activities in the novel that are considered to have occurred in the past. This study found that approximately $72 \%$ of data samples show the presence of temps passé composé. This has been stated by the translator of L'Étranger in the book of Orang Asing that there is a peculiarity in Albert Camus's writing style who prefers to use temps composé in the form of passé composé instead of using temps simple in the form of passé simple that is a typical standard tense in French writing [9]. 


\subsection{The Occurrence of Temps Verbaux (Verb Tenses) in The Translated Novel of Keberangkatan That is Le Départ}

Observations were not only made on French novel and its translated novel in Indonesian but also on Indonesian novel and its translated novel in French. The purpose is to see the words that do not recognize tense or temps in Indonesian obtain tense or temps in their French translation. The occurrence of verb tenses or temps verbaux in the translated novel of Keberangkatan can be seen in Table 2.

Table 2. The Occurrence of Temps Verbaux (Verb Tenses) in The Translated Novel of Keberangkatan That Is Le Départ

\begin{tabular}{|c|c|c|}
\hline \multirow{2}{*}{ No. } & \multicolumn{2}{|c|}{ TEMPS VERBAUX } \\
\hline & Keberangkatan (Indonesian) [11] & Le Départ (French) [12] \\
\hline 1. & $\begin{array}{l}\text { Harinya lembab berhujan kecil } \\
\text { (page 9) }\end{array}$ & $\begin{array}{l}\text { Il faisait plutôt humide ce jour-là à } \\
\text { cause de la pluie fine qui tombait. } \\
\text { (page 13) }\end{array}$ \\
\hline 2. & $\begin{array}{l}\text { Suara itu tiba-tiba } \\
\text { membangunkanku dari lamunan } \\
\text { (page 10) }\end{array}$ & $\begin{array}{l}\text { Cette voix soudaine interrompit ma } \\
\text { rêverie (page } 4 \text { ) }\end{array}$ \\
\hline 3. & $\begin{array}{l}\text { Aku merangkulkan lengan pada } \\
\text { leher adikku (page 10) }\end{array}$ & $\begin{array}{l}\text { Je pris ma petite sœur par les bras } \\
\text { (page 15) }\end{array}$ \\
\hline 4. & $\begin{array}{l}\text { Tanpa berkata-kata lagi, kami } \\
\text { berpelukan (page 10) }\end{array}$ & $\begin{array}{l}\text { Sans dire un mot nous nous } \\
\text { embrassâmes (page 15) }\end{array}$ \\
\hline 5. & $\begin{array}{l}\text { Aku melangkah mendekati } \\
\text { kumpulan keluargaku (page 10) }\end{array}$ & $\begin{array}{l}\text { Je fis quelques pas me rapprochant de } \\
\text { ma famille (page 14) }\end{array}$ \\
\hline 6. & $\begin{array}{l}\text { Tapi kali itu kami bekerja berdua } \\
\text { di dalam kabin. (page } 25 \text { ) }\end{array}$ & $\begin{array}{l}\text { Mais aujourd'hui nous étions deux en } \\
\text { cabine. (page 33) }\end{array}$ \\
\hline 7. & $\begin{array}{l}\text { Enam bulan terakhir itu suasana } \\
\text { tegang di mana-mana (page 26) }\end{array}$ & $\begin{array}{l}\text { Ces derniers six mois une situation } \\
\text { difficile s'était fait sentir dans tout le } \\
\text { pays (page } 35 \text { ) }\end{array}$ \\
\hline 8. & $\begin{array}{l}\text { Waktu itu tidak ada keharusan } \\
\text { untuk berganti nama (page 27) }\end{array}$ & $\begin{array}{l}\text { A cette époque il n'était pas } \\
\text { nécessaire de changer de nom (page } \\
\text { 36) }\end{array}$ \\
\hline 9. & $\begin{array}{l}\text { Hingga waktu itu, Rudi-lah yang } \\
\text { paling sering mengunjungiku (page } \\
\text { 32) }\end{array}$ & $\begin{array}{l}\text { Jusqu'à ce moment-là, c'était Rudi } \\
\text { qui venait le plus souvent me voir } \\
\text { (page 42) }\end{array}$ \\
\hline 10. & $\begin{array}{l}\text { Suatu petang aku tiba kembali dari } \\
\text { Manila (page 32) }\end{array}$ & $\begin{array}{l}\text { Un soir alors que je revenais de } \\
\text { Manille (page 42) }\end{array}$ \\
\hline
\end{tabular}

Table 2 presents the utterances in Indonesian that obtain temps verbaux in their translation on the French novel, Le Départ. Every word that has temps verbaux and its equivalent can be seen in bold words. The word harinya in the first Indonesian utterance obtain temps simple in the form of imparfait in its translation faisait. Temps simple in the form of imparfait can be identified by their verb form. Temps simple indicate the action is still in progress or not yet finished. The translation of the word harinya shows a similar context of tense or temps because harinya indicates unfinished activity.

In contrast to the first utterance, the second utterance has temps simple in the form of passé simple in its translation. Temps simple in the form of passé simple has the same meaning with temps composé in the form of passé composé. Temps simple should indicate unfinished activities 
but there is an exception in the temps passé simple. Temps simple in the form of passé simple indicates the completed activity or action. An example can be seen in the word membangunkanku translated to interrompit that is found in the second utterance. The word intterompit is a finished activity, but the temps contained in the translation is temps simple. Temps simple in the form of passé simple is identified by the absence of auxiliary verb and the distinctive verb form.

The same things also happen in the third, fourth, and fifth utterances where the utterances obtain temps simple in the form of passé simple that is identified by the absence of an auxiliary verb and the distinctive verb form. Pris is the verb that obtains temps verbaux from the translation of the word merangkulkan in the third utterance. The two words indicate a directly finished activity in the form of temps passé simple. The word berpelukan in the fourth utterance obtains temps passé simple in its translation nous embarassâmes. Berpelukan is one of the words whose activities will be directly finished. A verb that contains temps simple in the fifth utterance is fis (quelques pas). Fis (quelques pas) is a translation of the word melangkah in Indonesian that indicates a finished activity.

The sixth utterance obtains temps simple in the form of imparfait in one verb. The word is bekerja berdua which translated to nous étions deux. These two words indicate the context of ongoing activities or continuous duration activities. The seventh utterance obtains temps composé in the form of plus-que-parfait. Plus-que-parfait is identified by the presence of an auxiliary verb était with participe passé. The verb that contained temps verbaux is $s$ 'était fait sentir. S'était fait sentir is a translation of the word tegang in Indonesian. Both words show a finished activity or action.

The eighth, ninth, and tenth utterances obtain the same type of temps verbaux which is temps simple in the form of imparfait. The eighth utterance obtains temps verbaux in verb était nécessaire that is translated from the word ada keharusan. Meanwhile, the ninth utterance obtains temps verbaux on 2 words are Rudi-lah and mengunjungiku. The words translated into c'était Rudi and venait. Both words show unfinished activity or prolonged duratiotempn activity. The tenth utterance obtains com verbaux in verb revenais which is translated from the word tiba. To identify the appearance of temps imparfait, we have to pay attention to the form of the verb because every tense or temps has a distinctive verb form.

The results from the observation show that the entire utterances contain temps verbaux that describe events in the past. This happens because the story is depicted as a past event.

\section{Conclusion}

Based on the results, it can be concluded that the utterances containing verb tenses or temps verbaux have found in the French novel L'Étranger and their Indonesian equivalent show similarities in the context of tense or temps. The verb tenses or temps verbaux found in the utterances are temps simple in the form of imparfait and also temps compose in the form of passé composé and plus-que-parfait. The whole temps express the past activity or past state of being. Temps verbaux that dominate in French novel L'Étranger is temps composé in the form of passé composé which is Albert Camus's peculiarity in the novel. On the other hand, the utterances in the Indonesian novel Keberangkatan obtain verb tenses or temps verbaux in their French translation on Le Départ. The verb tenses or temps verbaux that are contained in the utterances are temps simple in the form of imparfait and passé simple, also temps composé in the form of passé composé and plus-que-parfait. The whole form of temps verbaux shows 
activities that have occurred in the past. Temps verbaux that dominate in the translated novel of Keberangkatan, which is Le Départ, is temps simple in the form of imparfait.

\section{References}

[1] Alwasilah AC. Pengantar Sosiologi Bahasa. Bandung: Angkasa; 1985.

[2] Nadar FX. Pragmatik dan Penelitian Pragmatik. Yogyakarta: Graha Ilmu; 2009. 227-228.

[3] Grevisse M. Le Petit Grevisse Grammaire Français. Paris: Larousse; 1988. 159.

[4] Samsuri. Analisis Bahasa. Jakarta: Erlangga; 1981. 251.

[5] Alwi H. Modalitas dalam Bahasa Indonesia. Yogyakarta: Kanisius; 1992.

[6] Martin J, Lecomte J. Grammaire Française. Paris: Larousse; 1962. 243.

[7] Sudaryanto. Metode dan Aneka Teknik Analisis Bahasa. Yogyakarta: Duta Wacana University; 1993. 27.

[8] Camus A. L’Étranger. Paris: Editions GALLIMARD; 1942. 7-15.

[9] Camus A. Orang Asing. $3^{\text {rd }}$ Edition. Translated by Apsanti Djokosujatno. Jakarta: Yayasan Pustaka Obor Indonesia; 2014. viii, 3-8.

[10] Hoed BH. Kala sebagai Pengungkap Waktu Kebahasaan dalam Novel Bahasa Perancis dan Padanannya dalam Bahasa Indonesia: Kajian Empat Novel Bahasa Perancis dan Terjemahannya dalam Bahasa Indonesia. Jakarta: Universitas Indonesia; 1989. 23.

[11] Dini N. Keberangkatan (Cetakan Ketujuh). Jakarta: PT. Gramedia Pustaka Utama; 2010. 9-32.

[12] Dini N. Le Départ. Translated by Lauren Metzger. Paris: L’Harmattan; 2013. 13-43. 